\title{
24
}

\section{GOOD GOVERNANCE AND DEVELOPMENT}

\author{
AID \\ Risks and Challenges of E-Government in Jordan
}

\author{
Claudio Ciborra ${ }^{1}$, Diego D. Navarra ${ }^{2}$ \\ ${ }^{l}$ Information Systems Department - LSE, UK, IULM - Milan; Institute of Informatics - \\ University of Oslo, Norway; ${ }^{2}$ Information Systems Department - LSE, UK
}

\begin{abstract}
Reforms and innovations in the governmental and bureaucratic apparatus of the nation-state are an important pre-requisite for development. This paper provides suggestive evidence that e-government and the related view of the neo-liberal state implicit in the good governance discourse put forward by the International Development Agencies might not be conducive to rapid late development. The New Institutional Economics as a background theory and Jordan as a case study show that a number of risks arising from external aid interventions are likely to exacerbate, and not resolve the problem of late development. The study is based on the analysis and design of e-government global solutions aimed at the creation of a neo-liberal state. It shows that implementing standardised ICT portfolio to support good governance may prove to be a very difficult task when contextual and other locally relevant variables are taken into account.
\end{abstract}

Keywords: E-government, good governance, LDCs, institutions, development, risk, Jordan.

\section{INTRODUCTION}

The recent efforts of G-8 countries to launch e-government projects to support 'good governance' in Late Developing Countries (LDCs) invite us to reflect on what is the role of the state proposed by the 'good governance' argument put forward by the International Development Agencies (such as the World Bank and the International Monetary Fund) and the scope of Information and Communication Technologies (ICTs) to enable the creation 
of such state. Specifically, to what extent can good governance as advocated by the 'Monterrey Consensus' contribute to development? What are the risks and challenges arising from the application of e-government in a late developing as opposed to an advanced state?

The alignment of International Development Agencies (IDAs), governments, civil society members and non-government organisations produced the 'Monterrey Consensus' in 2002 as a way to address key financial and development issues and to set development priorities for the next 20 years. Governance, which is a wide encompassing process involving the political, administrative and societal spheres of a country, is intended as 'good' when 'good policies' are implemented. In general terms, these policies have been reiterated in the Monterrey Consensus and are broadly aimed at: a) establishing democracy; b) eliminating corruption; and c) expand human capabilities.

A main point of the Monterrey Consensus is the introduction of ICTs in the development discourse and policy recommendations for LDCs, indicating that the creation of an information society, and especially egovernment implementation, would lead to good governance by increasing transparency and accountability of governments, reducing the transaction costs involved in service delivery by public bureaucracies (Ciborra, 1993) and enhancing the participation of citizens, businesses and civil society. Egovernment, in very general terms, is the use of Information and Communication Technologies (with a special new emphasis on the Internet) by government agencies and institutions, and the on-line provision of government services. This represents a new project for LDCs with plenty of risks and challenges still to be fully investigated.

In what follows, the case of Jordan will be discussed as an example of an e-government policy initiative. The case is of interest because of its advanced programs for the creation of the information society, including the launch of a world class software industry and the networking of the nation. It is one of the rare countries in the Middle East with a history of commitment to ICTs related initiatives and to good governance: in the words of Mahmoud Khasawneh, Chief Information Officer at the Jordanian Ministry for Information and Communication Technology, 'We have no choice but to do it'.

Section 2 will shed some light on the current debate surrounding egovernment and good governance in LDCs through a review of the New Institutional Economics literature. Section 3 presents the main contextual and organisational features of the Jordanian e-government initiative. In Section 4 the case study findings are put forward. Conclusions follow. 


\section{ON GOVERNMENT, GOVERNANCE AND THE ROLE OF ICTS IN LDCS}

\subsection{The Relationship Between E-Government and Good Governance}

E-government implies a drastic change in the way ICTs are used in government and a sharp departure from the 'traditional' way of working of government itself. While previous ICTs related efforts in the public administration were mostly based on the utilisation of technology for the automation of procedures, the achievement of cost savings and to streamline bottom-line performance, the goals of e-government are more ambitious. Namely, e-government means the use of the Internet for the provision of government services and the application of ICTs by government agencies in order to increase access to information and operational transparency, to improve service quality and delivery, and to raise social welfare. In general, the three main objectives of e-government are: a) restructure administrative functions and processes; b) overcome barriers to coordinate and cooperate within the public administration; and c) monitor government performance.

A crucial aspect is the way in which the relationship between state and citizens is expected to change. The shift to e-government requires an entirely new mindset in government and public administration; the latter becoming the interface between customers and provider of services, and not any longer between citizens and state. Hence, a cooperative interaction between citizens and public administration is crucial for successful implementation together with an overall organisational re-design of government's departments and agencies. Such a re-design should adhere to the tenets of the methodologies variously inspired to the Business Process Reengineering movement of the 1990s (see Ciborra, 2002).

To be sure, e-government is not applied in isolation: it is supposed to deeply affect the way in which a country is governed. Thus, according to Okot-Uma (2001: p.5) 'EGovernance seeks to realise processes and structures for harnessing the potentialities of information and communication technologies [...] for the purpose of enhancing Good Governance' (emphasis in the original). Governance is 'the way society collectively solves its problems and meets its needs [...]. In a framework of good governance, government services across administrative levels coordinate their activities in order to enhance the global effectiveness of policies and minimise conflicting action' (OECD, 2001: p.13). Accordingly, 'E-government initiatives should be measured by the degree to which they contribute to good governance' (UN, 2002: p.4). 
The process whereby conflicting action is minimised involves the creation of well-functioning institutions to smooth the operations of the market and allow free relationships of exchange to prosper. In particular, given the presumed role of ICTs in moving public bureaucracies toward a market model, one can conclude that e-government implementation tries to create a neo-liberal (or minimal) state.

\subsection{Good Governance, Development Aid and Policies}

The concept of good governance is better understood by looking at the underlying theory and the policies the government should implement. The development aid perspective is the one here privileged. Three main stages can be identified within the international aid allocation regime, with the multi-lateral IDAs setting widely followed guidelines for all donors: in the 1980s there were the Structural Adjustment Programs (SAPs); 1989 brought the 'Washington Consensus', while in the 1990s the emphasis shifted to 'Good Governance'. Table 1 below contains the main policy recommendations of the three approaches advised and supervised by the World Bank (WB) and the International Monetary Fund (IMF). The first two stages present obvious similarities in their stressing of privatisation, deregulation, and devaluation of the currency to contribute to macroeconomic balance: these policies have not been entirely abandoned in the 1990s.

Table 1. The evolution of the official guidelines for development assistance

\begin{tabular}{|c|c|c|}
\hline From 1980s: SAPs & 1989:Washington Consensus & 1990s: Good Governance \\
\hline $\begin{array}{ll}\text { - } & \text { Privatisation } \\
\text { - } & \text { Tax reform } \\
\text { - } & \text { Financial reform } \\
\text { - } & \text { liberadisation } \\
\text { Devaluation of } \\
\text { the exchange rate } \\
\text { - } \\
\text { Reduction of the } \\
\text { fiscal deficit } \\
\text { Deregulation of } \\
\text { markets and } \\
\text { agricultural price } \\
\text { reform }\end{array}$ & $\begin{array}{ll}\text { - } & \text { Privatisation } \\
\text { - } & \text { Tax reform } \\
\text { Public expenditure in } & \text { health, education, } \\
& \text { etc... } \\
\text { - } & \text { Trade liberalisation } \\
\text { - } & \text { Competitive } \\
& \text { exchange rate } \\
\text { - } & \text { Interest rate } \\
\text { - } & \text { deregulation } \\
& \text { Deregulation of } \\
\text { - } & \text { Fiscal discipline } \\
\text { - } & \text { Secure property } \\
& \text { rights }\end{array}$ & $\begin{array}{l}\text { Establishment of a } \\
\text { foundation of law } \\
\text { Maintenance of a } \\
\text { non-distortionary } \\
\text { policy environment } \\
\text { - } \quad \begin{array}{l}\text { Investment in basic } \\
\text { social services and }\end{array} \\
\text { infrastructure } \\
\text { Protection of the } \\
\text { vulnerable } \\
\text { Protection of the } \\
\text { environment }\end{array}$ \\
\hline Source: Weinhold (2001) & Source: Di John (2001) & Source: WB (1997a: 41-60) \\
\hline
\end{tabular}


Crucially, good governance requires the state to be involved in the creation, protection and enforcement of property rights, to provide a sound macroeconomic regime (thus including the previous recommendations) and to create institutions that limit state capacity for arbitrary action in order to improve its ability to support broad based markets (WB, 2002: pp. 99-101). The circulation of information through the free press and a vibrant civil society are also relevant, because the availability of information increases transparency, reduces corruption and promotes democratic governance (WB, 2002: pp.102-109).

\subsection{New Institutional Economics Principles and Implications}

The importance of institutions in the economy goes back to the pioneering work of Coase $(1937 ; 1960)$, who introduced the concepts of information and transaction costs to complement neoclassical economic analysis. Central to the research agenda of the New Institutional Economics (NIE) are the emphasis on property rights, the transaction costs of measurement and enforcement, and the role of incomplete information (North et al, 1996: p.1).

Institutions are humanly devised constraints that shape human interaction, define property rights and determine the costs of enforcement of rules and transacting in society. These costs, in turn, affect the costs of exchange and production and provide the incentive structure of the economy. By allocating property rights (or rents ${ }^{1}$ ), institutions provide opportunities, and are thus able to alter the behaviour of the agents in the economy. If the opportunities (or incentives) put forward by institutions are growth enhancing, the agents would respond by undertaking productive investments, otherwise they would engage in rent-seeking, leading the economy to stagnation (North, 1990: pp.1-10). According to North (1981) the lack of appropriate incentives and a weak property rights structure are responsible for state failure, and, one may add, underdevelopment.

In the NIE the next best alternative is the neo-liberal model, of the minimal, efficient state. But Khan $(1995 ; 2000 ; 2002)$ stresses that it is not only a matter of transaction costs and static efficiency. As a late developing state is typically in the process of transformation, there are high contestation and political transition costs caused by the bargaining process between the state-led reforms and other agents in the economy. Wade (1990) and Khan (2002) indicate that there is not enough empirical evidence to prove that the

\footnotetext{
1 Rents are incomes that individuals can earn that are higher than in their next-best opportunity and so rents exist if those in the next-best activities are prevented from getting access to particular resources or opportunities (Khan, 2002: p.7).
} 
minimal (or liberal) state is conducive to development, while states that have intervened aggressively and engaged in rent-management, according to the theoretical model of the developmental state have historically performed better. One has to manage effectively not only transaction costs but also transition costs (Ciborra, 1990). We refer to Figure 1 to illustrate the current debate.

Late development is a complex political process, with fast changing political and institutional structures and rapid capital accumulation. The outcome of policies and interventions can be successful (i.e. growth enhancing rents) or fail (i.e. growth reducing rents). The range of policies outcomes is represented by the horizontal axis in Figure 1. The 'appropriateness' of particular policies will be case specific and will depend on how these influence the consequent allocation of rents by state institutions. For example, enforcement will be easier if the policies promoted by the state will not go against politically organised, powerful or wealthy groups of LDCs. If the government is not able to win support from these groups the likely result will be fragmentation of interests leading to high rent-seeking costs. In Figure 1, such costs are expressed on the vertical axis as 'enforcement costs', measuring the aggregate rent-seeking costs (including lobbying bribery and corruption) of the policies promoted by the government. Growth will be highest when these aggregate costs are kept at a minimum coupled with effective enforcement by state institutions (as expressed in the bottom-right quadrant of Figure 1).

Outcomes of interventions and policies

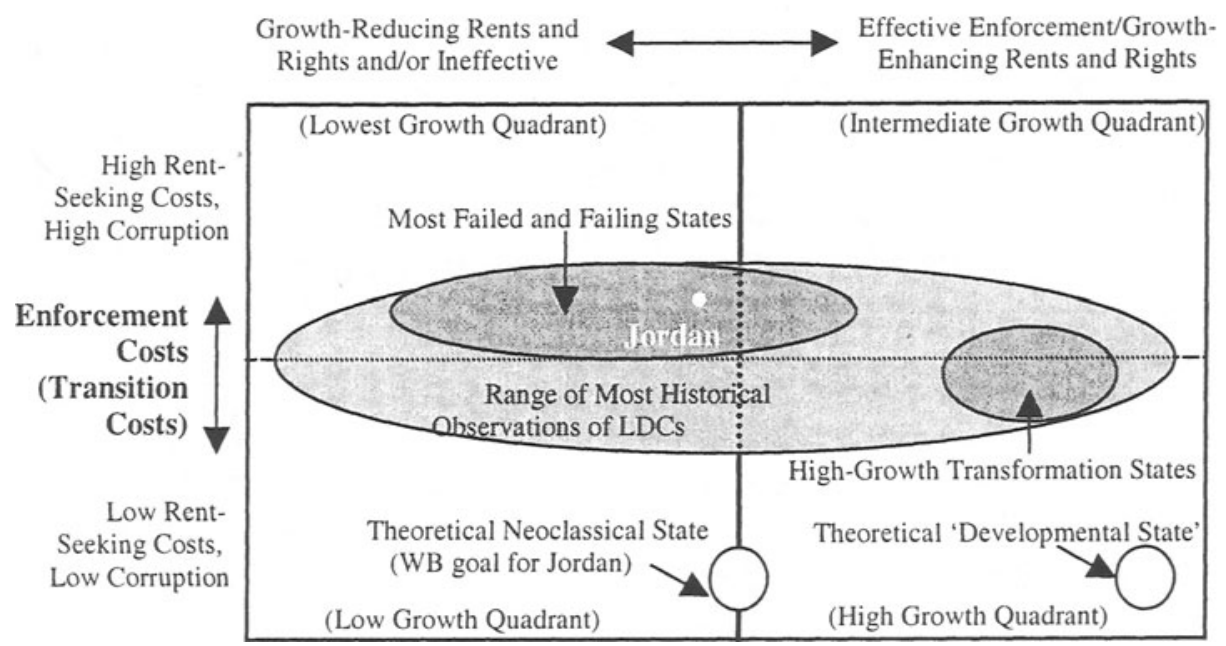

Figure 1. The process of transformation and the location of state failure. Adapted from Khan (2002:30) 
This depends not only on the ability of the state to choose specific policies, and allocate rents to productive groups accordingly, but also on the provision of incentives for long-term investment. The government needs to be credible over the long term, meaning that expropriation of the rents gained by the eventual investments of productive groups, will not take place. If the government is not able to initialise such productive processes, the risk would be to create a situation of high rent-seeking costs and growthreducing rents, where most failed and failing states are located (see the topleft quadrant of Figure 1).

On the other hand, credibility, low costs of enforcement and appropriate rents allocation, seem to have been the main strength of the development of South- East Asian economies in the 1960s, although those governments were not following the neoclassical state model. Particularly in Japan and Taiwan, the government played a key role for the allocation of rents and the overall industrial policy direction of their countries. Thus, South-East Asian economies are high-growth transformation states located between the top and bottom-right quadrant of Figure 1, while the theoretical neoclassical state (the WB 'ideal') lies between the bottom-right and bottom-left quadrant.

The Jordanian state belongs to the category of 'most failed and failing states' (see UNDP, 2002). According to the G-8 vision (DOT Force, 2002) e-government represents the promise for a rapid transition towards the theoretical neoclassical (neo-liberal or minimal) state. But what are the likely effects of e-government implementation in the Jordanian institutional and political context? What will be the likely costs of its enforcement? And which are actual, as opposed to the expected, outcomes? 


\section{THE CASE STUDY ${ }^{2}$}

\subsection{Jordan: Recent History and Key Statistics}

Jordan is landlocked between Iraq, Israel, Saudi Arabia, Syria and the West Bank; has a population slightly above 6,5 million and a land surface of about 91,000 sq. $\mathrm{Km}$, mostly desert. The country is governed by a constitutional monarchy headed by King Abdullah II. Since 1989 regular democratic elections have taken place and the government has implemented major reforms programs aimed at further increasing democratic participation, improving the provision of health care and education, and modernising the private sector as well as government agencies.

Literacy is very high in Jordan, with a formidable rate of $90 \%$ (UN Statistics Division, 2002). However, despite the dismantlement of the telecommunications monopoly started in 1997, together with market deregulation and privatisation, there are still less than 10 landlines and 2 internet users for 100 people. Hence Jordan ranks only 49 on the e-readiness report compiled by the Centre for International Development at Harvard University (see CID, 2002). Part of the explanation is that only $11 \%$ of Jordanian families have an income higher than US \$ 1070 per month (MoICT, 2000: pp.2-20), which makes personal computers and Internet connections virtually unaffordable to the greatest majority of the population.

With the assistance of the IMF and the WB, Jordan has tried to reduce the role of the state in the economy and boost the private sector's role and activities. However, progress has been inconsistent since the process began in the late 1980's. Despite Jordan being a member of the WTO since 2000, and benefiting from preferential trade agreements with a number of countries (including the US, the European Union and Japan) government services

\footnotetext{
${ }^{2}$ The methodology used was aimed at gathering qualitative material to describe both the planned and the vision of e-government in Jordan and collect elements of the current state of implementation. A case study research methodology was chosen because of the complexity of the observation, the inter-locking dependencies of multiple actors and organisations, and the paucity of empirical data available. The case study observation in Jordan lasted from the $24^{\text {th }}$ of June to the $6^{\text {th }}$ of July 2002. Primary sources of data have been collected from interviews with key people responsible for the major ongoing projects. The interviewees (about 20) included professionals and officials working in the government, the private sector, external consultants, non-governmental and donor organisations. During the interviews, which lasted between 45 and 60 minutes, open-ended questions were asked aimed at gathering an understanding of visions, strategies, models and methods being used; expected and actual organisational impacts; the influence of cultural factors in adopting standard solutions; especially the major risks and challenges facing e-government initiatives and specific projects.
} 
remain the largest single contributor to GDP, accounting for nearly $17.6 \%$ in year 2000 (Central Bank of Jordan Annual Report, 2000).

\subsection{E-Government in Jordan: Institutional Aspects}

The implementation of e-government in Jordan is at an early, but crucial stage. The governmental entity in charge of implementing e-government is the former Ministry of Post and Communication, now Ministry of Information and Communication Technology (MoICT). Having completed the design stage, the MoICT is in the delicate phase of co-ordinating with all other (often reluctant) government Ministries and departments to create a shared vision on e-government. According to Al-Jaghoub and Westrup (forthcoming) 'Jordan is an example of a nation state trying to develop using ICT in an increasingly globalised world', by promoting an ICT industry and following the competitive market-based model of the neo-liberal state.

The King is the single most important initiator of all ICT led projects. These are then filtered by the Ministry of Planning, supported and monitored by the MoICT, and then reviewed and implemented by other Ministries (especially the Ministry of Industry and Trade), the private sector and other non-governmental organisations (such as AMIR). The REACH (Regulatory Framework, Estate, Advancement Programs, Capital, Human Resources) initiative, for instance, represents the spirit of a public-private partnership approach. REACH, is supported by the Information Technology Association of Jordan (int@j), a non-profit private sector initiative that resides under the patronage of the MoICT. 'Connecting Jordanians' and the International Computer Driving Licence are other two parallel programs, the former under the patronage of the Jordanian government, while the latter is sponsored by the United Nations. Table 2 contains an initial list of the key actors involved in the above mentioned initiatives and the sources of funding (as of July 2002).

Jordan's e-government strategy is aimed at using new technologies to facilitate inter and intra-agency communication and cooperation, as well as provide information and services to its citizens more effectively. The program relies on four foundations: introduction of e-services, infrastructure development, education and training, and legal change. A number of Fast Track projects have been launched in 2001. They include motoring services (at Department of Driving Licenses and Motor Vehicles), taxation (income and sales) services, and land registry. Next will be the Government-toBusiness and Government-to-Customer portals and a Government Personnel Directory. A new network infrastructure is envisaged to enable government introduce knowledge management, empower and connect government staff. 
Table 2. External actors, sources of funding and aid projects

\begin{tabular}{|l|l|}
\hline \multicolumn{2}{|l|}{ EXTERNAL ACTORS } \\
\hline Consulting firms & $\begin{array}{l}\text { Deloitte \& Touche, } \\
\text { EDS }\end{array}$ \\
\hline Vendors & $\begin{array}{l}\text { Helwett-Packard, } \\
\text { Cisco Systems, } \\
\text { Microsoft, Intel, } \\
\text { Oracle }\end{array}$ \\
\hline $\begin{array}{l}\text { Multi-lateral donor } \\
\text { agencies }\end{array}$ & $\begin{array}{l}\text { USAid, UN } \\
\text { Development } \\
\text { Programme }\end{array}$ \\
\hline $\begin{array}{l}\text { Non-Governmental } \\
\text { Organisations }\end{array}$ & AMIR \\
\hline
\end{tabular}

\begin{tabular}{|c|c|}
\hline DONORS & PROJECTS \\
\hline $\begin{array}{l}\text { Spanish } \\
\text { Government }\end{array}$ & Hardware \\
\hline $\begin{array}{l}\text { Japanese } \\
\text { Government }\end{array}$ & Technical assistance \\
\hline $\begin{array}{l}\text { British } \\
\text { Council }\end{array}$ & $\begin{array}{l}\text { System testing and } \\
\text { quality assurance }\end{array}$ \\
\hline World Bank & $\begin{array}{l}\text { Hardware, technical } \\
\text { assistance, learning and } \\
\text { resources centres }\end{array}$ \\
\hline Islamic Bank & Teacher training \\
\hline $\begin{array}{l}\text { National } \\
\text { Plan }\end{array}$ & Basic schools \\
\hline $\begin{array}{l}\text { Cisco } \\
\text { Systems }\end{array}$ & Teaching assistance \\
\hline
\end{tabular}

In the Jordanian case, controlling the essential components of the egovernment apparatus involves a certain degree of centralisation. At the same time the organisations promoting it demand co-ordination and a certain degree of local autonomy. But as a steering committee in charge of the monitoring, co-ordination and evaluation of the projects linked to the egovernment initiative had not yet been established (at least at the time of the present study) many crucial projects were receiving the go-ahead without the appropriate conditions for competitive tendering.

\section{RISKS AND CHALLENGES}

Note that the creation of new institutions and organisations aimed at promoting the appropriate conditions for a neo-liberal form of state, which uses decentralisation and competition as a way to provide better services for the citizens/customers, is ultimately crafted under the directives of the current (non liberal) government. This leads to a number of inconsistencies. For example, Internet Cafes in Jordan are still under strict government regulation. This might be a first clue to suggest that 'e-Jordan' is not approaching the model of the neoclassical state wished for by the WB and other IDAs. More specifically, what are the costs of allocating the new rents of e-government and what is the likely level of effectiveness of the current projects? What could be the side effects when issues specific to the Jordanian context are taken into account? 


\subsection{A Mindset Change?}

The Minister of the MoICT has many times emphasised that a mindset change is needed for progress. Unfortunately, it is no guarantee that implementing e-government models and work methods will solve this issue.

Once the new system will start working, citizens will be required to pay for services. Presently, however, the value of these services is extremely difficult to estimate let alone understand the willingness and ability of the population to pay for them. In fact, there is no standard methodology to calculate the costs and benefits associated with providing such services. Last but not least, a senior member of government states that 'Investors and aid agencies demand reforms, not the people'. This statement is of great importance as it emphasises that while democratic governance is the objective, it is not appreciated by the citizens. Indeed, many decisions are taken at a level where there is no popular control, electoral or otherwise.

\subsection{Co-ordinating the Public-Private Partnerships}

There are a number of tensions in the dialectic between the political economy argument put forward by the IDAs and the reality of LDCs. For instance, e-government requires strong leadership to be successful, while at the same time it tries to promote decentralised and democratic organisational structures. The presence of a variety of consulting firms and donor agencies (see Table 2) requires a gigantic steering effort for their coordination. Unfortunately, neither the donors nor the government may be able to learn from past experience. A senior government official noticed that in the 1990s the greatest problem of a large ICT venture in Jordan was the lack of a single authority. Hence, it was difficult to define roles and track responsibilities and the multi-million US\$ project became almost a data graveyard.

In a nutshell, the theories, models and methodologies underlying egovernment implementation seem not be followed in Jordan's context. While these focus on a standard set of applications and call for a set of sequentially defined stages which are meant to be adhered to during implementation, according to a senior member of government: 'It is difficult to find who is in charge', and thus to promote real enforcement.

\subsection{Placing Jordan on the Map}

A number of administrative and contextual features help placing Jordan's trajectory among the quadrants of Figure 2. Along the horizontal axis what matters is the feasibility and the most likely outcome of the policies needed for e-government, given the specific structural characteristics of the Jordanian state. The overall approach is aligned with the current models of 
e-government in Western countries (Deloitte Research, 2001). The extent to which this conduct will be growth-enhancing, if compared with the exigencies of late developers as opposed to a developed state, is uncertain at this stage. On the other hand, IDAs and donors do not seem to be able to bring any alternative know-how to the one of the leading consultancies and vendors.

The Fast Track applications, the portals and the internal network, once implemented, are supposed to bring about gains in efficiency of service delivery and reduce internal co-ordination costs. However, the gains may be limited because certain services will not be fully privatised (e.g. driving licences), nor will be fully marketable. For example, a 'simple' product like the driving licence is in reality a security document, the issue of which requires several authorities of various Ministries. Hence, efficiency gains will result only if the Jordan state reforms its inner workings and political purpose. Unfortunately these wide-ranging and cross-sectoral reforms do not feature in the Jordan e-government agenda. As a result, one would expect only limited, even if positive, growth enhancing rents being promoted by egovernment: hence the location of e-Jordan on the right -half of the horizontal axis, but not far from the central axis.

Moving now to the vertical axis, other cultural and context specific issues need to be taken into account. The first point to note is the absence of feedback mechanisms, which only a previously instituted democracy, a critical press and competitive recruitment of public sector officials could bring about, thus resulting in a serious problem of credibility of the government with respect to the Jordanian productive groups. Also, the presence of Palestinian immigrants holding many of the private sector activities in the country is a factor that should not be undervalued, since the reforms proposed by e-government are skewed in favour of the private sector. This is a signal of the presence of fragmented interest groups, meaning that public sector Jordanian workers might hinder the process with a certain degree of resistance, halting effective coordination of projects and policies. 
Outcomes of interventions and policies

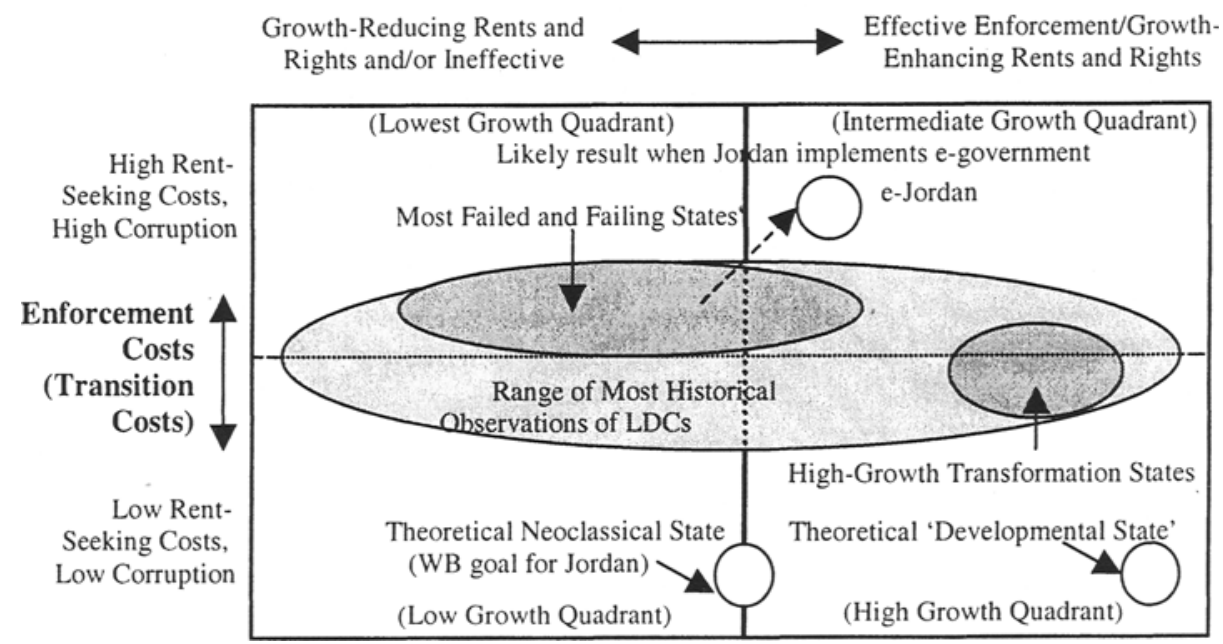

Figure 2. The location of the Jordanian state as a result of e-government implementation

Furthermore, respondents reported cases where some Ministries and private sector lobbies have often come together to write the new legislation required for the implementation of e-government. Whereas this would be a practice approved in a 'developmental' state model, it is what e-government is supposed to remove. In the case of Jordan, this could signal a reluctance to fully implement the changes required for e-government applications to take off with a citizen-centred focus. In sum, the present analysis suggests that egovernment related methodologies may not reduce the costs of transition, hinting instead at the fact that transaction costs and other challenges might even rise in the immediate short-term.

As a result, while e-government aims at moving failed and failing nations towards the theoretical neoclassical state, it can be inferred that even if the Jordanian institutions were able to implement their interventions, the costs of enforcement would still remain high, resulting at best in a situation of intermediate growth as shown by placing Jordan in the upper right quadrant of Figure 2.

\subsection{Technical Knowledge Dependence and Other Concerns}

At the moment, while different platforms are 'donated' to different Ministries in an incremental fashion, the risk is not only to create the basis for future problems of incompatibility, but also to implement solutions that are not fit for government agencies. The latter would be locked-in by high 
replacement costs, which would only benefit the suppliers of such systems. Considering also that $95 \%$ of the government's budget comes from loans and grants, if aid flows are decreased the government will not be able to afford and maintain all the latest 'state of the art' equipment.

Furthermore, due to the widespread lack of IT skills among Jordanians, software and personal computers vendors would have the ultimate say on the design of the infrastructure. Should a problem occur, it will be in the hands of the 'outsourced' big firms to fix it, and a breakdown is likely to stop the government machine entirely. Obsolescence will be a problem too. One should also keep in mind that the multinationals providing technical assistance and products need after all to make 'business sense' of their donations. On the other hand, any downgrading in the level of security of the region, may provoke the sudden evacuation of key experts and maintenance personnel.

\section{CONCLUSIONS}

The present study of the Jordan's e-government initiative suggests that the current view on how to achieve good governance embedded in the 'Monterrey Consensus' is not frictionless. Also, when taking into account the specific context in which LDCs' governments operate, potentially damaging side effects could arise. Perhaps, the greatest challenges to the implementation of e-government are the low competence of donors in allocating and managing the funds, the increased complexity of the state apparatus and the push for democratic reforms without real popular participation from either the people in LDCs or from the developed nations.

The implementation of e-government is bound to encounter the same old problems (such as redundancy, incompatibility, unclear requirements, difficulties in control) related to the creation of major ICT infrastructures (Ciborra et al., 2000). Moreover, even if implemented, there are still serious doubts that it would be the best solution for Jordan (as well as for other LDCs), due to concerns of ex post opportunism by vendors and external interventions exacerbating the structural constraints of LDCs (Wade, 2002).

The case study indicates that:

1) Even if public-private partnerships can help rebuild state capacity in developed nations, this may not be substitute for effective governance in LDCs;

2) LDCs willing to implement e-government should have a strong efficient state ex ante, as e-government may not be conducive to a strengthened state capacity, per se; 
3) Better chances of e-government success may reside in using it as a learning experiment for local adaptation, rather than as an implicit regulatory instrument.

\section{ACKNOWLEDGEMENT}

We thank all the people who spared some of their precious time to help us during our study in Jordan. Special thanks for their kindness and hospitality are for Dema and Mahmoud of the MoICT and to Basma.

\section{REFERENCES}

Al-Jaghoub, S. and Westrup C. "Jordan and ICT Led Development: Towards a Competition State?", (forthcoming in Information Technology and People).

Central Bank of Jordan, "Central Bank Thirty Seventh Annual Report 2000", Research Department, Central Bank of Jordan, 2001.

Ciborra, C. "X-Efficiency, Transaction Costs and Organizational Change", in On X-Efficiency Theory, Weiermair. P. (Ed.), Ann Arbor: University of Michigan Press, 1990.

Ciborra, C. Teams, Markets and Systems, Cambridge.: Cambridge University Press, 1993.

Ciborra C. (ed), From Control to Drift: The Dynamics of Corporate Information Infrastructures, Oxford: Oxford University Press, 2000.

Ciborra, C. The Labyrinths of Information: Challenging the Wisdom of Systems, Oxford: Oxford University Press, 2002.

CID, "The Global Information Technology Report 2001-2002: Readiness for the Networked World", Center for International Development, Harvard University, 2002.

Coase, R.H. "The Nature of the Firm", Economica, (4), 1937, pp. 386-405.

Coase, R.H. "The Problem of Social Cost", Journal of Law and Economics, (3:1), 1960, pp. $1-44$.

Deloitte Researce, E-Government's Next Generation: Transforming the Government Enterprise Through Customer Service, New York: Deloitte Consulting (Global), 2001.

Di John, From Bretton Woods to the Post-Washington Consensus, unpublished, DV 400 Public Folders, LSE, 2001.

DOT Force, Digital Opportunities for All, Report Card, Digital Opportunities Task Force, 2002.

Economist Intelligence Unit, Country Profile: Jordan, March. London: The Economist Intelligence Unit Limited, 2002.

Khan, M. and Jomo, K. S. Rents, Rent-Seeking and Economic Development: Theory and Evidence in Asia, New York: Cambridge University Press, 2000.

Khan, M. "State Failure in Weak States: A Critique of New Institutionalist Explanations", in The New Institutional Economics and Third World Development, Harris et al. (eds.), London: Routledge, 1995.

Khan, M. "State Failure in Developing Countries and Strategies of Institutional Reform", draft Paper for the Annual Bank Conference on Development Economics, 2002.

MoICT, Launching E-Government in Jordan: Readiness and Approach, 2000.

Nahapiet, J. and Ghoshal, G. "Social Capital, Intellectual Capital and the Organisational Advantage" in The Strategic Management of Intellectual Capital and Organisational Knowledge, Choo, C. W. \& Bontis, N. (eds.), Oxford: Oxford University Press, 2002. 
North, D.C. Structure and Change in Economic History, New York: W.W. Norton, 1981.

North, D.C. Institutions, Institutional Change and Economic Performance, Cambridge: Cambridge University Press, 1990.

North, D.C., Alston, L.J. and Eggertsson, T. (eds.). Empirical Studies in Institutional Change, Cambridge: Cambridge University Press, 1996.

OECD, "Local Partnerships For Better Governance", OECD Publications, 2001.

Okot-Uma, R. "Electronic Governance: Reinventing Good Governance", London. Commonwealth Secretariat, 2001.

UN Statistics Division, On-Line Database. Available at: http://unstats.un.org/unsd /default.htm. (Accessed at: March 12, 2002).

$\mathrm{UN}$, Final Communiqué of the International Conference on E-government for Development, Conference Proceedings, 2002.

UNDP, Human Development Report 2002: Deepening Democracy in a Fragmented World, New York.: Oxford University Press, 2002.

Wade, R.H. Governing the Market, Princeton. Princeton: University Press, 1990.

Wade, R.H. "Bridging the Digital Divide: New Route to Development or New Form of Dependency?", Global Governance, (8:4) (forthcoming), 2002.

Weinhold, D. "Stabilisation and Structural Adjustment: A Very General Overview", unpublished, DV 409 Public Folders, LSE, 2001.

World Bank, "World Development Report 2002: Building Institutions for Markets", Washington: World Bank, 2002.

World Bank, "The World Bank Annual Report 1997”, Washington: World Bank, 1997a.

\begin{abstract}
About the Authors
Claudio Ciborra is PwC Professor of Information Systems and Risk at the London School of Economics and Political Science. His research has focussed on issues of technology, organization, strategy and innovation. He also teaches at IULM, Milan and is Visiting Professor at the Oslo University. He has published many articles and books on information systems. His latest is titled "The Labyrinths of Information - Challenging the Wisdom of Systems". He can be reached by e-mail at: c.ciborra@lse.ac.uk.

Diego D. Navarra is a doctorate student in the Information Systems Department at the London School of Economics. He is doing research on the role of the government in late developing countries for the implementation of ICTs policies and the institutional obstacles to effective ICT implementation. He has recently finished his MSc in Development Management at the London School of Economics and can be reached by email at: d.d.navarra@lse.ac.uk.
\end{abstract}

